\title{
Dansk på stedet - skitse til en omgivelsesforankret læringsmetode
}

\author{
Line Hjorth Christensen, adjunkt, ph.d. ved Institut for Nordiske Studier og Sprogvi- \\ denskab, Kфbenhavns Universitet, lhc@hum.ku.dk.
}

\section{Reviewet artikel}

Ud fra en konkret undervisnings- og udstillingscase på Københavns Universitet Amager undersøger artiklen, hoordan det nære fysiske miljø på uddannelsesstedet kan indgå som ressource i en konkret danskfaglig laringssammenhæng. Der tages afsæt $i$ det forhold, at de fysiske omgivelser er et undervurderet aspekt $i$ læringssammenhænge og $i$ en forståelse af, at kunsten bevxger sig frit på tværs af forskellige medier, hoor litteratur og sprog altid er $i$ dialog med andre bevidst formgivne udtryk af ikke-sproglig karakter. Der redegøres for den konkrete case, for kursets og den specifikke øvelses faglige mål, såvel de museologisk danskfaglige som de fagdidaktiske samt for de teoretiske inspirationer og overvejelser, der ligger til grund for at arbejde med udstillingsmediet $i$ danskundervisningen. På den baggrund redegøres der for de studerendes reaktioner på lyrikprojektet $i$ forhold til fagfaglige og didaktiske mål; afslutningsvist opsummerer artiklen med sigte på metodens relevans for danskundervisningen og på humaniora.

I begreber som "studiemiljø", "undervisningsmiljø" og "uddannelsessted" er omgivelserne indlejret og indikerer sammenhæng mellem fysisk miljø, undervisning og læring. Men selv om terminologien tilkendegiver sammenhæng, og undervisning altid kan siges at foregå et sted i rummet, er det langt fra en dimension, der i alle tilfælde integreres og tillægges pædagogisk betydning. Ofte fortoner omgivelserne sig i praksis som betydningsløs baggrund og anonym kulisse, selv om en række videnskabelige discipliner for længst har anerkendt omgivelsernes betydning for læringsprocessen. ${ }^{1}$

Artiklen belyser en øvelse, som blev afviklet i relation til et kandidatkursus i Anvendt Museologi på danskfaget ved Københavns Universitet, Institut for Nordiske Studier og Sprogvidenskab (herefter INSS), hvor øvelsens produkt - en lyrikudstilling og et katalog - indgik i en offentlig kulturbegivenhed, Kulturnatten 2009. ${ }^{2}$

\footnotetext{
${ }^{1}$ Falk and Dierking (2000).

${ }_{2}^{2}$ KU deltager årligt i Kulturnatten, et landsdækkende kulturarrangement, som i København startede i 1993. Museer, gallerier, kirker, musiksteder, uddannelsesinstitutioner, ministerier, foreninger, biblioteker og mange flere åbner dørene for arrangementets titusindvis af besøgende. Formålet er "at stimulere den kulturelle nysgerrighed og oplevelsesevne hos børn og voksne, og meget gerne sammen"; samtidigt håber de mange institutioner at tiltrække et nyt publikum, som ellers ikke besøger kulturinstitutioner. (KUs hjemmeside). 
Øvelsen er inspireret af udstillingsæstetiske og kunstnerisk stedsspecifikke tilgange og lægger sig endvidere i forlængelse af forskellige typer af erfaringspædagogisk og æstetisk undervisningspraksis. Æstetisk praksis bruges her som et udtryk for sæt af deskriptive, kontekstualiserende og oplevelsesrettede tilgange til et område eller udpeget symbolsystem - i dette tilfælde udstillingsmediet specifikt og udstillingskataloget som en paratekst eller relateret element, der angiver en fortolkningsramme for udstillingen. ${ }^{3}$

Som sit overordnede formål ville projektet tilvejebringe et perspektiv, der gav den enkelte studerende mulighed for at få nye syn på sig selv og sit fag. Ideen var at afprøve, hvordan et studiemiljø uden for de gængse undervisningsområder kan integreres i undervisningen, og hvordan man bevidstgør om og motiverer til at opløse kunstige barrierer mellem litteratur og andre kunst-, kultur- og livsformer. Som udgangspunkt bygger tilgangen på en fundamental forståelse af, at kunsten i sig selv bevæger sig frit på tværs af forskellige medier og på en erkendelse af, at litteratur og sprog altid er i dialog med andre bevidst formgivne udtryk af ikke-sproglig karakter. ${ }^{4}$

Casestudiet belyser, hvordan en visuel og materiel repræsentation af digte, primært fra det 20. Århundrede, blev afsæt for en relateret mediering af stoffet i et udstillingskatalog, og hvordan sammenhængen mellem fysisk og skriftlig formidling affødte en række didaktiske pointer. Artiklen tegner, sammenholdt med andre tilsvarende initiativer, der afsøger forbindelser mellem materiel kultur og visuel, rumlig formidling, et rids til en omgivelsesforankret, æstetisk læringsmetode. ${ }^{5}$

Arkitektur- og designteorien har løbende belyst og engageret sig i en debat om, hvordan såvel permanente, fysiske rammer som visuelle udtryk af mere flygtig karakter generelt indvirker på vores adfærd og har ydet vigtige bidrag til at belyse den fysiske dimensions betydning for læring. ${ }^{6}$ Over for dette perspektiv, de faste omgivelsers generelle betydning for læring og læringsadfærd, fokuseres der her på, hvordan omgivelserne kan indgå i universitetsundervisningen, så der skabes situationer, hvor studerende aktivt præger og gør sig erfaringer i dialog med den fysiske og sociale verden. ${ }^{7}$

Mens der i gymnasiets danskfag (stx) er traditioner for rumlig, æstetisk praksis i relation til litteraturundervisning, som også implicerer museologisk arbejde og relaterer

\footnotetext{
${ }^{3}$ Om paratekst i museologisk sammenhæng, se Hejlskov Larsen og Thorhauge (2008).

${ }^{4}$ Gregersen, Mortensen m.fl. (2003).

${ }_{5}^{5}$ Christensen (2010); (2012).

${ }^{6}$ Kjærvang (2011); Krampen (2002).

${ }^{7}$ For en nuancering af læring der betoner kropsforankring og aktivitet se Moser (2007).
} 
sig til steder uden for uddannelsesstedet ${ }^{8}$, er universitetet det institutionelle omdrejningspunkt i denne artikel. Det æstetiske studie- og undervisningsmiljø forstås i bred forstand som et, der både danner rammen om den skemalagte undervisning og om faglige aktiviteter i og uden for kurser og obligatorisk undervisningstid. Dette miljø inkluderer, men rækker også ud over arkitekturen som en fysisk bygget struktur i form af organiske udemiljøer, indretning, eventuelle udsmykninger på stedet og, som casen demonstrerer, æstetiske aktiviteter. ${ }^{9}$ Dertil bør tilføjes forskellige typer af studiefaglige og socialt motiverende faciliteter, hvor biblioteker, studiepladser, specialeskrivningsrum og studentercafeer har central betydning for et alsidigt og levende studiemiljø. ${ }^{10}$

\section{Idé, form, formål}

Kandidatkurset Anvendt Museologi på INSS bestod i efteråret 2009 af et hold på 15 studerende. Kurset lægger som et fast element op til, at centrale sprogligt symbolske og litterære kompetencer aktiveres og relateres til andre kunstformer og kulturelt betingede udtryk, genstandssamlinger, arkiver og museal formidlingspraksis. I fokus for dette semesters undervisning var museer og udstillingers tekstgenrer, eksempelvis kataloger, hjemmesider, markedsføring og andre eksterne formidlingsformer. Dertil trænes udstillingskritik, -analyse og anmeldelse med vægt på, hvordan medieringer af kulturarv danner egne betydningssystemer af genstande, rum og sprog. Holdets studerende var primært indskrevet på danskfaget, men jf. universitetets vision om et tværfagligt orienteret "indre marked" med øget kontakt til andre fag, er kurset åbent for deltagere udefra. ${ }^{11}$

Den semiotiske forståelse af udstillingen som en form og til måder, hvorpå denne form konstrueres og skaber betydning, var udstillingsøvelsens teoretiske afsæt. I en vekslen mellem forskellige læringsmetoder oparbejdede holdet en viden og et afsæt for udadvendt, selvstændigt udstillingsarbejde. ${ }^{12}$ Inspireret af rejseguidens format og collageagtige karakter fungerede udstillingskataloget Lyrikfører som en ramme om-

\footnotetext{
${ }^{8}$ Mai (1998) oplister eksempler fra senhalvfemsernes danskfagsundervisning i gymnasiet, bl.a. med reference til Thavenius (1995); nyere eksempler på, hvordan museologiske læringsprocesser integreres i gymnasieundervisning er projektet Intrface, et samarbejde mellem museer og gymnasier i Region Midt, se http://www.intrface.dk.

${ }^{9}$ Kjærvang (2006).

${ }^{10}$ I min forskning og undervisning har biblioteket på INSS flere gange indgået som et udpeget sted og en del af pensum, bl.a. i forbindelse med udstillingsprojekter (Christensen, 2012) og i belysning af historiske sammenhænge mellem museum og bibliotek.

11 “Videnssamfundets kompleksitet betyder, at tværfaglige kompetencer, herunder kompetencer i at samarbejde på tværs af fag og kulturer, bliver et afgørende konkurrenceparameter. Derfor indeholder Københavns Universitets strategi Destination 2012 en vision om, at KU's studerende i højere grad skal have mulighed for at komme i berøring med andre fag end blot deres eget.", jf. http://kuur.ku.dk/indremarked/.

${ }^{12}$ Christensen (2012).
} 
kring den fysiske installations blandede forfatterpræsentationer ${ }^{13}$, litterære værker og begreber, ligesom rejsetemaet skulle associere til at se udstillingen som en rejse ind i lyrikkens verden. Denne pointe blev understreget af et grafisk layout, der lånte fra forsiderne på Politikens kendte guidebogserie Turen går til... ${ }^{14}$ Genrens sproglige og visuelle format stillede dermed krav til, at de studerende skrev sig ind i en særlig fremstillingsform og -tradition og udforskede denne forms muligheder og begrænsninger.

Udstillings- og katalogarbejdet lå, qua den korte afstand til Kulturnatten i oktober, først i semestret, som påbegyndes første uge i september. I praksis bevirkede fristen, at der i det korte tidsrum blev skabt en række komprimerede fælles erfaringer og konkrete produkter, og at de studerende i lange perioder opholdt sig på universitetet. Det intense forløb involverede foruden skemalagte timer arbejde henover en weekend og flere lange studiedage, hvor man var optaget af installering og teknik, tekstredigering og grafisk tilrettelæggelse. Holdet var inddelt i 4 temagrupper med ansvar for hver deres lyrikere og periode. Desuden meldte flere sig til frivillige opgaver. Bl.a. skrev to studerende i samarbejde en artikel om udstillingen, som blev trykt i fakultetsbladet Humanist.

Af de i alt fjorten undervisningsgange optog forberedelserne de første fem understøttet af forelæsning og tekstgennemgange, fremlæggelser m.v. Introduktioner til udstillingsæstetik og -analyse og til museets tekstgenrer var del af et pensum, der også skulle give det praktiske udstillingsarbejde faglig tyngde. Den stadige vekslen mellem kendte akademiske undervisningsformater, ekskursioner og øvelser, mellem direkte erfaringsbaserede læringsmetoder med høj grad af deltagerstyring og problemorienteret undervisning i samspil med lærerstyret undervisning, gav på skift mulighed for at indhente direkte erfaring, fordybe sig i og reflektere over disse erfaringer i forhold til det øvrige pensum.

Konkret bestod vandreudstillingen af syv monumentale bøger af ca. 2 meters højde, som ankom i dele, pakket i store transportkasser fra det forrige udstillingssted, Det Kgl. Biblioteks Diamanten. ${ }^{15}$ Bøgerne kunne opleves indefra og udefra, hvor hver bog visualiserede et digt eller et forfatterskab, bl.a. en spilleautomat med "maskindigte" systemdigtning af Inger Christensen og Klaus Høeck, dertil et komplet toiletinteriør med "lokumsdigte", et tableau i Lego med reference til Johs. V. Jensens digt "På

\footnotetext{
${ }^{13}$ Morten Søndergaard, Ursula Andkjær Olsen, Naja Maria Aidt, Klaus Høeck, Inger Christensen, Johs. $\mathrm{V}$. Jensen og Oehlenschlager var repræsenteret i udstillingen.

14 "Digte for begyndere og let øvede", Anvendt museologi efteråret 2009.

${ }^{15}$ Installationen er oprindeligt skabt i samarbejde med designere og billedkunstnere og er støttet af en kampagne for læselyst og af Ny Carlsbergfondet. Flere forfattere har undervejs været impliceret, bl.a. Søren Ulrik Thomsen og Ursula Andkjær Olsen. Ideen er udviklet i samarbejde med billedkunstnere og designere under en workshop i Katalyst - et væksthus for humanistisk innovation og iværksætteri, under Det Humanistiske Fakultet.
} 
Memphis Station", et karikeret skattekort over steder i Oehlenschlägers Guldhornene samt et komfur, hvori lyrikeren Morten Søndergaard, på film, læste egne digte. Ifølge udstillingens initiativtager cand. mag. Lise Gram var ideen:

"at lave en udstilling, der skulle gøre digte mere tilgængelige. Poesi har ry for at være smalt og elitxrt; jeg blev motiveret af en tro på, at mange flere vil have glæde af at lxse digte. Jeg havde lyst til at dele den poetiske læseglæde og oplevelse med andre". ${ }^{16}$

Ud fra dette formål realiserede udstillingen en række møder mellem hverdagskulturelle fænomener og "smal", "elitær" digtekunst, mellem det visuelle, rumlige og det litterære. En evaluering havde tidligere vist, at mange besøgende fandt den sprogløse formidling af den modernistiske og helt nye lyrik vanskelig ${ }^{17}$ - digtene lod sig ikke så let formidle uden ord. Da disse reaktioner i sagens natur modsagde arrangørernes pædagogiske hensigt, kom kritikken i stedet til at danne afsæt for et nyt formidlende lag og blev en del af museologikurset.

Installationen blev vist $\mathrm{i}$ et højloftet, glasindrammet gangareal i stueplan på INSS, som ligger i Nye KUA (fremover kaldet KUA1) og består af en samling aflange bygninger i beige sandsten med front mod Njalsgade. Stedet præges af åbne områder, store vinduespartier mod tilsvarende bygninger, en retlinet minimalisme i sten og stål, grå, sort og hvid. I det daglige fungerer gangarealet både som befærdet strøg og gennemgang til kantine, undervisningslokaler, studentercafé og trappearealer og er præget af spredt beliggende øer med åbne studiepladser. I lighed med den udendørs parisercafés vue mod gaden og bylivet kan man fra disse pladser skiftevis orientere sig ud i rummet eller fordybe sig i læsning eller samtale med medstuderende, se og blive set. På Kulturnatten understøttede stedets livlige atmosfære og udstillingen gensidigt hinanden; holdet blev aftenen igennem overdraget ansvaret for at afholde åbningstale og omvisninger, tale med publikum, dele kataloger ud samt give interviews til den lokale presse.

\section{En øvelse til forskel - medieringens pointer}

Øvelsens erfaringsbaserede tilgang finder grund i 1970'ernes og 1980'ernes erfaringspædagogik..$^{18}$ Men hvor erfaringspædagogikken fortrinsvist er blevet praktiseret på folkeskole- og gymnasieniveau og har sat elevernes egen erfaringsverden i centrum af læreprocessen, havde udstillingsøvelsen på INSS også andre fagligt kvalificerende mål end den genkendelse, selvrefleksion og subjektivitet, der især har præget erfaringspædagogikken. Fokus var her rettet mod de studerendes arbejde med udstillingen som et særligt medium med specifikke form- og betydningsskabende

\footnotetext{
${ }^{16}$ Lyrikfører, introduktion.

${ }_{17}$ Udstillingsevaluering, samtaler med Lise Gram og upubliceret tekst om udstillingen.

18 Mai (1998).
} 
egenskaber og var forankret i det nære studiemiljø, der således blev afgørende for medieringsprocessen.

I de følgende afsnit nuanceres og begrebsliggøres de didaktiske pointer, medieringen nærmere førte med sig, og som danner grundlaget for videre undersøgelser af, hvordan omgivelsesforankret læring virker og kan udvikles i praksis. Austring og Sørensen beskriver mediering som "den proces, hvori den enkeltes udtryk tilpasses og omformes i forhold til et valgt medie" og fremhæver, at:

"Beskæftigelsen med medier kræver både kendskab og kunnen, hvad angår specifikke teknikker og metoder. Det at udtrykke sig kreativt via et medie forudsætter, at man mestrer det, altså at man har kendskab til mediets form-og indholdsmæssige konventioner, at man mestrer dets teknik og metodik, og endelig, at man har en kunnen $i$ forhold til at bearbejde materialet. ${ }^{19}$

I den praktiske undervisningssituation er det sjældent muligt at oparbejde kompetencer på det ideelle niveau, citatet opstiller, et niveau, hvor de studerende når at "mestre" kuratoriske kompetencer. I senmodernismen har kurateringsfaget da også antaget stadig mere kompleks karakter og er efterhånden etableret som selvstændig profession. ${ }^{20}$ På den anden side opnår deltagerne indsigt i og kendskab til museologisk teori og praksis og får dermed en faglig ballast, som udvikles yderligere i en vekslen med øvelsens medieringsprocesser.

Da udstillingsbaseret undervisning (her defineret bredt til også at indbefatte enhver type symbolsk mediering relateret til selve kurateringsarbejdet) qua udstillingens karakter er rumligt og fysisk forankret, og da al læring synes at være uløseligt forbundet med de omgivelser, hvori den finder sted, skaber kombinationen undervisning/udstilling et frodigt didaktisk terræn. Gennem medieringer af et fagligt stof facilliteres for det første en optik, hvori ikke bare stedet selv ophører med at fremstå anonymt, gennemsigtigt, men hvor det faglige indhold tilsvarende fremhæves, bearbejdes og dermed tydeliggøres i den enkeltes bevidsthed. Udstillingsarbejde går lidt groft sagt ud på at fremhæve, ophøje eller på anden vis indramme betydninger ved og ud fra et særligt materiale; i denne proces inkluderes, ekskluderes, forhandles og produceres betydninger, ${ }^{21}$ og arbejdet er, hvad enten det foregår som led i øvelse og undervisning eller i en professionel udstillingssfære, altså på ingen måde neutralt. Denne pointe synes helt central for øvelsens didaktiske afkast og for den omgivelsesforankrede metode, øvelsen skitserer konturerne af. Man kunne betegne det som en måde, hvorpå såvel stedets som stoffets betydninger afnaturaliseres og træder i karakter som signifikante, betydningsfulde.

\footnotetext{
${ }^{19}$ Austring \& Sørensen (2006).

${ }^{20}$ Hansen, Olsen m.fl. (2012).

${ }^{21}$ Hansen (2012).
} 
I forlængelse heraf er et andet karakteristika ved den type mediering, som øvelsen realiserede, at lyrikken i udstillingens omgivelsesforankrede format fik kollektiv appel i forhold til det trykte digts individrettede karakter. I sin fastholdelse af bogen som bærende skabelon - men her en bog i et overdimensioneret, forvrænget format fremstod den som en ironi over læsningens individrettede art, fordi de syv monstrøse bogværker udvidede perspektivet fra synssans til sansning af litteratur med syn og krop, hvor beskueren som nævnt kunne træde ind i og ud af bøgerne, fysisk føle sig "lille" og symbolsk indtage rollen som "begynder" jf. udstillingens titel. Metoden fraveg på den måde typer af læring, der ensidigt opfatter teksten som bundet til synet, bogen og læseakten. På grund af det valgte medium, udstillingen, blev omgivelserne (det nære studie- og undervisningsmiljø) et integreret, nødvendigt aspekt af øvelsen.

Forløbets snævre tidsramme bevirkede, som en tredje didaktisk pointe og til dels uventet, at såvel øvelsens sociale aspekter, de færdige produkter og selve gennemførelsen på Kulturnatten blev tilbagevendende referencer for det resterende semesters undervisning og en markant erfaring, som det øvrige pensum blev holdt op imod. Med det, Polanyi i sin teori om tavs viden betegner "den fænomenologiske struktur", den del af aktiviteten, som er nær på og ikke italesat, kan man sige, ${ }^{22}$ at den kompleksitet af situationer, der udspillede sig undervejs i processen, blev et stof, de studerende efterfølgende bearbejdede, gjorde til genstand for refleksion og satte ord på i nye opgaver, tekstgennemgange og eksamensopgaver. Denne tredje pointe kan man betegne som en efterfølgende, kontinuerlig bearbejdelse af tavs viden.

For David A. Kolb, amerikansk læringsteoretiker og initiator af den erfaringsbaserede læringsretning "experiential learning", er netop bearbejdningen af den erfaringsbaserede empiriske oplevelse afgørende for læringsprocessen:

"The simple perception of experience alone is not sufficient for learning; something must be done with it. Similarly, transformation alone cannot represent learning, for there must be something to be transformed, some state or experience that is being acted upon." (1984, s. 42).

Læringsbegrebet defineres i Kolbs optik ud fra begreber som proces og handling og som noget, der forudsætter en direkte erfaring med eller oplevelse af et stof, og dernæst en handling, som kræver, at et objekt eller en problemstilling relateres til "andre forhold", hvor et materiale transformers eller medieres fra et medium til et andet. ${ }^{23}$

Udstillingsøvelsen eksemplificerer konkret, hvordan der kan arbejdes med sammenhænge mellem miljø og læring i en aktiv, deltagerorienteret form, en kobling, der

22 Sandager (2004).

${ }^{23}$ Kolb (1984). 
genfindes hos den pragmatiske filosof og pædagogiske reformist John Dewey, en hovedinspirationskilde for Kolb. Deweys omfattende og fortsat aktuelle teorier bygger på en grundopfattelse af individets tilknytning til omgivelserne, en tankegang, der bl.a. kommer til udtryk i en grundlæggende betoning af, at livet slet og ret foregår i et miljø og i gensidig udveksling med det:

"The first great consideration is that life goes on in an environment; not merely in it but because of it, through interaction with it. No creature lives merely under its skin; its subcutaneous organs are means of connection with what lies beyond its bodily frame, and to which, in order to live, it must adjust itself, by accomodation and defence but also by conquest." (1934, s. 12).

Særligt iagttagelsens biologiske karakter og fremhævelsen af den kropsligt bestemte tilpasningsproces til omgivelserne er, hvor evident den end kan virke, relevant og aktuel også for herværende case. Den menneskelige organisme må ikke alene aktivt tilpasse sig omgivelserne, men også erobre dem, et forhold, der aktualiseres og styrkes i projekter som det her beskrevne forløb. Deweys tilgang begrænser sig ikke til at være ensidig fysisk-biologisk men anerkender, at tankevirksomhed har dybe biologiske dimensioner og også fundamentalt er et socialt fænomen - at vi som individer indgår i kontinuerlige interaktioner med en variation af omgivelser, der på én gang er af fysisk, social og kulturel karakter. ${ }^{24}$ At interaktion med omgivelserne er et grundlæggende livsvilkår, giver også god mening i et konkret læringsperspektiv, hvor der, jf. øvelsen, arbejdes fagdidaktisk og omgivelsesbevidst.

For øvelsens del var det i spændet mellem tilpasning (til de eksisterende omgivelser), et forudgående kendskab (til stedet og lyrikken) og en (selv)erobring af et kendt stof på en ny måde, at læringsprocessen udspillede sig. En studerende udtrykte det på følgende måde:

"Jeg vil ikke sige, at jeg lærte noget egentligt nyt om selve genren lyrik, men jeg lærte meget om andre måder at tænke lyrik (litteratur) på, altså idéen $i$ at give lyrik nyt liv $i$ andre kunstformer. Tænke litteratur som "inddragende", frem for "ensom", og på en anden måde end højtlæsning eller teater."

Det er tydeligt nok ikke en isoleret erkendelse af lyrikkens karakter, der har været øvelsens afkast for denne studerende. Snarere har medieringen af lyrikeksemplerne til en anden kunstform vitaliseret erfaringen af lyrikken ("give lyrik nyt liv i andre kunstformer"); en erfaring, der er inkluderende frem for ekskluderende, og som afspejler, at udstillingens omgivelsesforankrede og multisensoriske karakter har virket

\footnotetext{
${ }^{24}$ Det er værd at mærke sig, at det biologisk, kropsfunderede aspekt ved Deweys teoridannelser også danner central inspiration for en kognitiv lingvist som George Lakoff, der bl.a. anerkender slægtskabet i Lakoff (1999).
} 
stærkere end andre kollektive medier ("Højtlæsning eller teater"). Den tværæstetiske oplevelse og bearbejdning af stoffet bliver en metode til det, man også kan se som en af erfaringspædagogisk afledt "læsestrategi", hvor begreber som 'meddigtende tekstlæsning og selvtematisering' er blevet beskrevet som en mulig ny måde at arbejde med danskfaget på. ${ }^{25}$ Denne erfaring betegnes her som en positiv revitalisering af et allerede kendt stof.

Som det er fremgået, lader medieringsprocessens didaktiske pointer sig beskrive ud fra det, der her listes i fire karakteristika, hvor stedet og det faglige stof (eksempelvis problemstilling/emne/genstande m.v.) afnaturaliseres og opnår ny signifikans; er kendetegnet ved en kollektiv appel frem for en individrettet henvendelsesform; finder sted som en bearbejdelse af tavs viden, når erfaringerne fra øvelsen holdes op imod kursets øvrige pensum og bliver reference og refleksionspunkt, samt det forhold, at medieringen medvirker til at revitalisere et allerede kendt fagligt stof, når dette stof omsættes fra et medium (bogen/teksten) til udstillingens flerdimensionale formsprog.

Mens erfaringspædagogikken, herunder Deweys og Kolbs pointeringer af samspil mellem omgivelser og læring, danner et basalt lag i øvelsens teoretiske fundament, kan øvelsens stedsspecifikke formidling af lyrik endvidere sammenholdes med typer af kunstneriske strategier, der operationaliserer steders fysiske og symbolske egenskaber. Frem for at definere et gennemgående træk ved den tilgang, som i kunstteorien betegnes stedsspecifik kunst, er denne snarere kendetegnet ved en bred vifte af udtryk. Den stedsspecifikke kunst, der især vandt udbredelse i 1990'erne, beror på en fundamental bevidsthed om og interesse for stedets "ånd" og dets særlige betydningsskabende karakter. Kunsthistoriker Anne Ring Petersen har i en artikel om kunstnergruppen Tapko beskrevet den stedsspecifikke tilgang som noget, der kan finde sted på mange måder og niveauer:

"Koblingerne mellem værk og sted kan befinde sig på forskellige planer, ligesom bindingerne til lokaliteten kan være af varierende intensitet." 26

For kunstens del er der tale om strategier, som i den ene ende af en skala arbejder ud fra en tilgang, der lader rummet og dets referencer være styrende for udførelsen af et værk, og hvor forbindelserne mellem værk og sted er af en sådan karakter, at værket vanskeligt kan tænkes uden for dette særlige sted, værket er af en midlertidig karakter og forsvinder, når udstillingen lukker. I en anden ende af skalaen finder man

\footnotetext{
${ }^{25}$ Mai (1998). Her refereres til en udstilling af kunstnerisk udformede unikabøger, hvorom det bl.a. hedder, at "de formidlingsmæssige og didaktiske muligheder, udstillingen demonstrerer, er ikke vanskelige at tage i brug i undervisningen." - en tese, artiklen dog ikke underbygger nærmere.

26 Petersen (1998:91).
} 
værker, der i højere grad besidder interne relationer og kan tilpasses et sted, men hvis grundform er tilrettelagt forud for en udstilling. ${ }^{27}$

Da lyrikudstillingen på INSS udsprang af en foruddefineret form, var mulighederne for at tilpasse og forandre begrænsede. Til gengæld blev tilpasningen præget af instituttets faglige grundlag, af et i forvejen eksisterende sprogligt og litterært miljø, integreret i den skriftlige arbejdsproces, der havde til hensigt at synliggøre forbindelser mellem den fysiske udstilling og de studerendes fortolkninger af det materielle stof og meddigtende formidling af de syv bøgers form og indhold.

\section{Læring i virkeligheden: mediering $i$ en offentlighedssfære}

Ovenfor er der redegjort for nogle af de vigtigste didaktiske pointer, øvelsens medieringsprocesser fremkaldte. Afslutningsvist vil jeg fremhæve øvelsens anvendte karakter med fokus på det forhold, at den overskred konventionelle undervisningsformater ved at flette sig ind i et offentligt arrangement med et "rigtigt" publikum.

Som nævnt var det et primært mål at skabe kendskab til museologien og oparbejde udstillingsanalytiske og formidlingsmæssige kompetencer. Af evalueringer fremgår det, at denne funktionsbetingede tilgang havde stor betydning:

"Jeg mener, at jeg lærte en del om udstillingsmediet, hvad det kan, og hvordan det virker eller ikke gør."

En anden studerende argumenterede for:

"... det er en god og spændende udfordring at skulle formidle et medie til et andet, hvor hele processen op til og omkring udstillingen var interessant og resulterede $i$ overvejelser i forhold til praktiske, museologiske aspekter og problematikker."28

Besvarelsen uddyber senere kommentaren om "at formidle et medie til et andet" og understreger relevansen af at arbejde med udstillinger i et danskfagligt perspektiv. Den fagdidaktiske pointe underbygges af en anden udtalelse om fordelene ved at omsætte et danskfagligt stof i en udstilling:

"Det fremmer danskfagligheden, ved at man pludselig skal omsætte viden til noget konkret. Man kunne sige, at udstillingsarbejde kunne blive for danskfaget, hoad fysikken er for matematikken, nemlig et mere praktisk område, hoor man kan bruge teorien i praksis. Vi lærer jo på dansk at formulere os og at genkende andres formuleringsfejl, og på en udstilling bliver det gjort tydeligt, om man har formået at formulere sig, så brugeren får noget ud af udstillingen."

\footnotetext{
${ }^{27}$ Disse ville kunne flyttes til nye sammenhænge, genopstå i nye konstellationer og former, og er på den måde mere mobile og fleksible (Petersen, 1998).

${ }_{28}^{2}$ Evalueringsspørgsmål, Anvendt Museologi, efterår 2009.
} 
Øvelsen etablerede et laboratorium, men ikke et lukket, internt rum og ikke et, hvor praksis stod alene, da metoden flerdimensionalt benyttede andre tilgange, tekstlæsning/teori, museumsbesøg etc. Anvendelsesfunktionen fremhæves af flere studerende, hvor det også fremgår, at mediering af viden til noget, der får betydning i "virkelige" udadvendte sociale sammenhænge og med positivt udbytte for andre mennesker, var en gevinst også for de lærende selv:

"Det havde stor betydning for mig, at der var en deadline og "rigtige" mennesker, der skulle opleve og vurdere vores indsats. Universitetet trænger til i det hele taget at relatere sin undervisning til verden udenfor."

Ved at arbejde i og med studiemiljøet og række ud mod "rigtige mennesker" og "verden udenfor", skabte øvelsen sit eget på en gang åbne og lukkede læringsrum. Derved modsatte den sig det problem, at "de virkelige omgivelser" ofte aktivt afvises af undervisningssystemer på mange niveauer, også når det gælder de omgivelser, der ligger snublende nær, en afvisning der af studerende kan opleves som en afskærmning og mangel på relationer til den omgivende verden. ${ }^{29}$ I stedet blev "virkeligheden" trukket indenfor og opladt med den autoritet og energi, der af universitetsstuderende ofte tillægges miljøer uden for universitetets egen zone.

Den skriftlige proces, tilrettelæggelse og udarbejdelse af guiden gav mulighed for at træne skriftlige og litterære kompetencer i et virkelighedsnært format, ligesom dette arbejde lå inden for en tidsgrænse og en genre, der fordrede målrettet faglig sprogbrug. Endvidere åbnede processen, frem for en på humaniora udbredt norm om individuel tekstproduktion, for at læse, diskutere og redigere hinandens tekster, give og modtage kritik. I relation til den fysiske udstilling etablerede guiden således et parallelt spor fra idéudvikling, skrive- og redigeringsfase til omdeling af den færdige guide til kulturnattens besøgende. Den offentlige ramme, kulturnat og publikum, går igen som en motivation for engagement og arbejdsindsats i projektet:

"Selve det at have en deadline og at skulle vise det frem, også til fremmede, var enormt godt for projektet, i mine øjne. Kulturnatten er altid et tilløbsstykke, og dermed kom der automatisk publikum i udstillingen."

At undervisningen foregik uden for det almindelige undervisningslokale og som del af et offentligt arrangement udvidede, efter én studerendes mening, også muligheden for, hvad der "normalt" kan lade sig gøre i undervisningen, og giver et særligt ansvar:

"Det kan være rigtig fint, at noget "bare" er en øvelse, hvis den $i$ så fald bliver holdt $i$ det lokale, hoor undervisningen normalt foregår, og hvor man i så fald diskuterer

${ }^{29}$ Kolb (1984). 
øvelsen på et mere teoretisk plan, fordi man ikke har virkeligheden at prøve den af $i$. Men hvis man lader øvelsen leve i virkeligheden, som vi gjorde ved at være en del af et kulturarrangement, så skylder man sig selv og publikum at behandle det som virkelighed, på trods af at man samtidig afprøver øvelsens mekanikker."

Forskydningen fra gængse lokaler til et nyt rum og ny undervisningssituation blev af andre tolket som en personlig læringsgevinst:

"Når man rykker folk ud af deres normale læringsrammer, ændres snakken mellem dem også, det kan være nemmere, sjovere og mere udfordrende at diskutere ting. Man kan komme til at se det faglige i nyt lys, måske man forstår nogle ting bedre, når man ser det begynde at ske omkring én."

Skiftet af omgivelser ses her som et, der affødte nye måder at kommunikere på, et "nyt lys" at se stoffet i. Iagttagelsen bakkes op af undersøgelser, der har vist, at læringsprocesser påvirkes af de fysiske omgivelser men på en måde, hvor undervisningssituationer på helt nye steder er mindre fordelagtige for indlæringen end i miljøer, hvor den lærende i forvejen har kendskab til en bestemt type miljø. ${ }^{30}$

Mens øvelsen og pensum i øvrigt var ukendt eller nyopdyrket fagligt land for de studerende, var stedet til gengæld en på forhånd kendt faktor, der også rummede mindre positive oplevelser af det daglige universitetsmiljø:

"KUA og INSS er ikke det mest inspirerende sted at lave udstillinger, rammerne er langtfra optimale. Stedet har altid mindet mig om et hospital med de blanke flader og lange gange. KUA er indbegrebet af en "institution", hvilket jeg ikke tror er stimulerende for laringsprocessen. Jeg vil hellere ud og møde nogle mennesker, gå på udstilling, sidde i et tog og få undervisning; sådan larer jeg bedst."

Opfattelsen af den sterile institution sættes her over for læring "i det åbne". Mens modstillingen "inde"/"ude" måske overrasker mindre, er den til gengæld væsentlig at indregne i planlægningen af kommende forløb for derved at tydeliggøre og udnytte erfaringer fra kursets ekstramurale aktiviteter i de dele af forløbet, der har mere traditionel karakter. ${ }^{31}$ Lyrikprojektet bestræbte sig på at etablere sådanne forbindelser, bl.a. ved at opfordre til at integrere og udfolde projektet i eksamensopgaven. Dog er det nødvendigt, at der om muligt arbejdes mere målrettet med at koble "indenfor" og "udenfor" og med at differentiere såvel eksterne som interne rum og steders særlige karakter og didaktiske muligheder og brug.

\footnotetext{
${ }^{30}$ Referencen vedrører skolebørns læringsmønstre(Falk and Dierking, 1992).

${ }^{31}$ Ekstramuralt forstås her som steder, hvor læring finder sted uden for skolens mure og ikke er formelt forankret i læseplaner, officielle bekendtgørelser og faglige mål.
} 
Tilsvarende var det en klar erfaring fra forløbet, at læring, der implicerer genstande, materialer og kuratorisk arbejde, fremmer dialog, socialt engagement og fælles indsats frem mod et konkret mål. Museologisk æstetiske læringsmetoder, som den her beskrevne, ansporer til videre at undersøge, hvordan det nære miljø kan integreres bedre i undervisningen og i forhold til et fags enkelte elementer og faglige formål. Casen beskriver processen i et danskfagsdidaktisk perspektiv, men det synes oplagt, at det nære miljø også kan indgå i aktive processer i relation til andre fagområder. Dels fordi stedet, uanset hvilket nyt fagligt stof, der introduceres, forbliver en kendt, stabil faktor, dels fordi processen at omsætte et stof til et andet medium udfordrer og giver mulighed for at reflektere faglighedens "egenart". Enten fordi den udfoldes i forhold til andre fagligheder eller krænges ud i sammenhænge uden for uddannelsesstedet.

Endelig peger øvelsen fremadrettet på, hvor væsentligt det er, at enhver kritik, der hævder, at humaniora er isoleret fra "virkeligheden" (hvad enten den kommer indefra eller udefra), ikke fejes til side som en klichéagtig vurdering men derimod ekspliciteres, belyses og diskuteres åbent i undervisningen. Ikke for at give op over for en kritik om et virkelighedsfjernt humaniora, men for at rejse spørgsmålet, hvordan uddannelser i de humanistiske fag og dermed en humanistisk livsindstilling i øget grad kan indvirke på og få samfundsmæssig relevans og gøre sig gældende i sammenhænge uden for fagene selv. Her viste lyrikøvelsen, at didaktisk aktivitet og bearbejdning af uddannelsesstedets egne rum, blanke flader og åbne gennemgangsarealer med fordel kan være et sted at begynde.

Line Hjorth Christensen er adjunkt, ph.d. ved Institut for Nordiske Studier og Sprogvidenskab og arbejder inden for forskningsfelterne museologi, didaktik og kulturformidling, I sin seneste forskning har hun beskxftiget sig med danskfaget $i$ kuratoriske, fagdiaktiske og formidlingsmæssige perspektiver. I 2012 udgiver hun en designhistorisk monografi om plakaten som grafisk design- og udstillingsobjekt, Plakatbevægelsen - en britisk designfront i mellemkrigsårene, på Museum Tusculanums Forlag. Line Hjorth Christensen er ansvarshavende redaktør af tidsskriftet Danske Museer og medlem af redaktionskomiteen for tidsskriftet Nordisk Museologi.

\section{Litteratur}

Arbejdsgruppen Fremtidens Danskfag v. Gregersen, F., Mortensen F. H. m.fl. (2001). Fremtidens danskfag - en diskussion af danskfaglighed og et bud på dens fremtid. Uddannelsesstyrelsens temahæfteserie nr. 1-2003, Undervisningsministeriet.

Austring, B. D. \& Sørensen, M. (2007). Æstetik og læring, grundbog om æstetiske læreprocesser. Hans Reitzels Forlag.

Bjerre, P. \& Standrup, M. (2009). Træd ind i poesien. Humanist, oktober 2009.

Christensen, L. H. (2012). Vejene mellem sprog og museum: æstetisk læring i danskfaget. I Gericke, N. \& Schüllerqvist, B.(red.) Ämnesdidaktisk komparationländer, ämnen, teorier, metoder, frågor och resultat. NOFA 3, Karlstads Universitet, pp. 90102. 
Christensen, L. H. (2011). Maskespil - udstillingen som viden og didaktisk eksperiment. I Nielsen, H. J., Høyrup, H., \& Christensen, H. D. (red.) Nye Vidensmedier, kultur, læring, kommunikation, Samfundslitteratur, pp. 279-296.

Christensen, L. H. (2007/1).Museum Studies. An Anthology of Contexts - en anmeldelse af museumsantologi v. Bettina Messias Carbonell, Blackwell 2004. I Nordisk Museologi, pp. 145-151.

Dewey, J. (1934/2005). Art as Experience. New York: Perigee.

Falk, J. H. \& Dierking, L. (1992). The Museum Experience. California: Left Coast Press, Inc.

Falk, J. H. \& Dierking, L. (2000), Learning from Museums. Visitor Experiences and the Making of Meaning. California: Alta Mira Press.

Hansen, M. V., Olsen, S. K., Petersen, L. J. \& Ratcliffe, M. N. (2012). Kuratering af samtidskunst. Roskilde: Museet for Samtidskunst.

Kjærvang, U. (2006). Ad æstetikkens vej mod bedre læring. DCUM.dk: http://dcum.dk/undervisningsmiljoe/ad-aestetikkens-vej-mod-bedre-laering.

Kolb, D. A. (1984). Experiential Learning, Experience as the Source of Learning and Development. New Jersey: Prentice Hall PTR.

Krampen, M. (2002). Semiotics in Architecture and Industrial/Product Design. I Margolin, V. \& Buchanan R. (eds.) The Idea of Design - A Design Issues Reader. Cambridge, Mas.:The MIT Press, pp. 89-103.

Lakoff, G. \& Johnson, M. (1999) Philosophy in the Flesh, the Embodied Mind and its Challenge to Western Thought. New York: Basic Books.

Larsen, A. H. \& Thorhauge, S. (2008). Museumsgrundbogen - kunsten at læse et museum, Aarhus: Systime.

Mai, A. (1998). Unika. I: Dalsgaard, I., Hansen, M. \& Ingerslev, G. (red.) Midt i Ræset en artikelsamling om dansk. Frederiksberg: Dansklærerforeningen, pp. 13-36.

Moser, T. (2007). Kropsforankret læring og aktivitet som pædagogiske begreber. I Schilhab, T. S. S. \& Steffensen, B. Nervepirrende pædagogik. København: Akademisk Forlag, pp. 120-141.

Petersen, A. R. (1998). Provisoriske positioner. I Tapko - Sunday Morning Walk, Kunsthallen Brandts Klædefabrik, pp. 85-96.

Poulsen, R. K. (2009). Poesi i øjenhøjde. Humanist 32, marts 2009.

Sandager, K. (2005). Æstetiske læreprocesser og flerdimensionel læring. I Schnedler, C. J. Bredde og dybde i undervisningen: Astetiske læreprocesser. Esbjerg: CVU Vest Press, pp. 24-47.

Thavenius, J. (1995). Den motsägelsesfulla bildningen. Stockholm: Brutus Östlings Bokförlag Symposium.

Materiale og evalueringer fra kandidatkursus i Anvendt Museologi, danskfaget, Institut for Nordiske Studier og Sprogvidenskab, Københavns Universitet, efteråret 2009; Digte for begyndere og let øvede (Lyrikfører).

http://www.ku.dk

http://kuur.ku.dk/indremarked

http://www.intrface.dk 